\title{
Promišljanja o dokumentu „Communio sanctorum: Toward a Theology of the Church as a Fellowship of Persons“ Petera Kuzmiča i Miroslava Volfa, u kontekstu dijaloga između Pentekostalne i Katoličke Crkve
}

\author{
Ciprian Gheorghe-Luca \\ Faculty of Humanities and Social Sciences of the 'Aurel Vlaicu' University of Arad, Romania \\ ciprian.luca@uav.ro
}

UDK: 279.15:27-67 Izvorni znanstveni članak https://doi.org/10.32862/k1.15.1.6

\section{Sažetak}

Svrha je ovoga članka promišljanje o pentekostalnom načinu razumijevanja zajedništva svetih, slijedom kritičkog bavljenja eklezijalnom vizijom dvojice svjetskih pentekostalnih teologa iz postkomunističkih zemalja: Petra Kuzmiča i Miroslava Volfa. Članak se sastoji od tri dijela: u prvom je dijelu predstavljen kratak povijesni i teološki pregled doktrine communio sanctorum, sa svrhom uspostavljanja primjerenog konteksta za daljnja razmatranja te jasnog ukazivanja na korisnost razmišljanja o ovoj važnoj ekleziološkoj temi. Drugi dio donosi pregled dokumenta "Perspektive Koinoniae“ (Završno izvješće s Treće petogodišnjice pentekostalno-rimokatoličkog dijaloga), usredotočujući se na prvi krug razgovora (Riano, Italija, 1985.) koji su se odvijali na temu razumijevanja pojma communio sanctorum. $U$ trećem dijelu, autor predstavlja i komentira dokument Kuzmiča $i$ Volfa „Teologija Crkve kao zajedništva osoba", koji predstavlja jedan od najranijih pokušaja artikuliranja pentekostalne ekleziologije temeljem poimanja communio sanctorum. Autor na kraju pokazuje kako ova ekleziološka vizija pomaže pri oblikovanju pentekostalne teologije javnoga društvenog života.

Ključne riječi: communio sanctorum, pentekostalizam, ekleziologija, zajedništvo svetih, ekumenski dijalog, teologija javnoga društvenog života 


\section{Kratak povijesni i teološki pregled communio sanctorum}

Moglo bi nas iznenaditi da, povijesno gledano, pojam zajedništvo svetih relativno kasno ulazi u „najšire prihvaćenu vjeroispovijest zapadnog kršćanstva“ (Pelikan 2005, 187). Premda najvjerojatnije potiče iz Bizanta (grčki izraz koinonia ton hagion predstavlja ekvivalent latinskom communio sanctorum), rečeni se pojam ne pojavljuje u Nicejsko-carigradskom, kao ni u Starom rimskom vjerovanju. Prvi se puta spominje u okviru Nicejskog vjerovanja (370. - 414., vidi Burn 1905, lxxx) u Remensiani, današnja Bela Palanka u suvremenoj Srbiji, u to vrijeme na glavnoj prometnici između Zapadne Europe i Carigrada, koji je tada slovio kao „Novi Rim“. Također, spominje se u Jeronimovu vjerovanju, koje potiče iz razdoblja 342. - 420. U VI. stoljeću postaje iskazom vjere u okviru Galicijskog vjerovanja, a Rim ga univerzalno integrira u Apostolsko vjerovanje tek pretkraj VIII. stoljeća.

Mišljenja znanstvenika o teološkom značenju ove fraze su i danas podijeljena. Neki su tvrdili da pojam zajedništvo svetih nikada nije predstavljao jasnu doktrinu te da je podrazumijevao mnoga tumačenja, čime je za brojne vjernike zadržao ambivalentno značenje (Carson i Cerrito 2003, 34). Pojam je zapravo bio izrazito zanemaren i zaslužuje naziv „spavajućeg simbola“ (Johnson 1998, 9; Imbelli 1998, 24-5). William Barclay, Charles Heurtley i J. N. D. Kelly slažu se da se značenje pojma communio sanctorum mijenjalo tijekom povijesti Crkve. Barclay $(1967,291)$, primjerice, tvrdi da taj pojam ima nejasno značenje, prije svega zbog hermeneutičkih i dogmatskih poteškoća pa više predstavlja tehnički crkveni pojam, dok Heurtley $(1858,146)$ i Kelly $(1981,389-97)$, poznati po svom pionirskom i opsežnom radu na temu ranokršćanskih vjerovanja, primjećuju da se različite perspektive razumijevanja značenja ove fraze pojavljuju jer je isprva vladala manjkava sigurnost o stvarnom značenju drugih odrednica Apostolskoga vjerovanja. Ipak, neki su suvremeniji znanstvenici, poput Leonarda DeLorenza sa Sveučilišta Notre Dame, pokušali dokazati sakramentalno i mistično (sve-sveto) značenje, ističući da je „zajedništvo svetih nedvojbeno obilježje kršćanske imaginacije koja je u skladu s otajstvom spasenja" (DeLorenzo 2017, 7). ${ }^{1}$ Stoga, ne iznenađuje da većina evanđeoskih kršćana, koja općenito zastupa ekleziologiju

1 Za više bibliografskih jedinica o povijesnom razvoju ove doktrine, posebice iz tradicionalne/ sakramentalne perspektive, vidi Jaroslav Pelikan. 2005. Credo: Historical and Theological Guide to Creeds and Confessions of Faith in the Christian Tradition. New Haven: Yale University Press; Stephen Benko. 1964. The Meaning of Sanctorum Communio. London: SCM Press; J. N. D. Kelly. 1972. Early Christian Creeds. New York: Longman; Susan Wood. 2004. "The Holy Catholic Church, the Communion of Saints." U: Roger Van Harn, ur. Exploring and Proclaiming the Apostles' Creed, str. 219-232. Grand Rapids: Eerdmans; Berard Marthaler. 2007. The Creed: The Apostolic Faith in Contemporary Theology. New London, Connecticut: Twenty-Third Publications; Nicholas Ayo. 1990. The Creed as Symbol. Notre Dame: University of Notre Dame Press. 
„slobodne Crkve“, često zanemaruje bilo koji (mogući) sakramentalni značaj ovog pojma, u korist izrazitije društveno usmjerenog razumijevanja zajedništva.

Lako se uočava da postoje dva latinska izraza koja oblikuju ovaj pojam: 1) communio (od grčkog koinonia), što znači zajedništvo, te 2) sanctorum (od grčkog hagios), što znači svet te može ukazivati na sancta (svete predmete) ili pak na sancti (svete osobe). Iako između katolika i evanđeoskih kršćana (što uključuje pentekostalce) nema velikih teoloških nesuglasica o implikacijama samog pojma communio - obje se strane slažu da je zajedništvo biblijsko i od ključne važnosti za Crkvu, ipak značenje cijele fraze communio sanctorum ili sanctorum communionem (kako se ponekad koristi) jest problematično i stoga diskutabilno. Što su kršćani IV. ili VIII. stoljeća imali na umu kad su ovu frazu koristili kao iskaz svoje vjere o Crkvi? Odnosi li se ovaj pojam na zajedništvo sa "svetim predmetima“ (sakramenti u kojima su sudjelovali) ili na zajedništvo među osobama? Štoviše, je li ovo zajedništvo bilo ograničeno na okupljenu zajednicu „aktivnih“ vjernika ili je uključivalo i „pobjednike“, tj. pokojnike koji su već otišli kod Gospodina?

Iako neki katolički teolozi daju prednost potonjem tumačenju (mistično zajedništvo živih svetih s mrtvim mučenicima), drugi ga ne odobravaju, tvrdeći da to ne može biti razlog integriranja ovog pojma u Vjerovanje. Badcock (1938, 246-47) je, među ostalima, kritičan u odnosu na povezivanje ove fraze s doktrinom o svetima, s obrazloženjem da je svrha Vjerovanja naglasiti nepromjenjive istine koje su nužni uvjet spasenja te su nepromijenjene od Pedesetnice naovamo. Uvjerljivo se tvrdilo da primitivno kršćanstvo nije znalo ništa o "posebnim“ svetima pošto su se svi kršćani smatrali takvima (Benko 1964, 71) i da zajedništvo svetih ne može značiti zajedništvo živih i mrtvih kršćana jer na Pedesetnicu još nije bilo mrtvih kršćana (Badcock 1938, 246-47).

Prije nego što se okrenemo središnjem dijelu našeg rada - pentekostalnom razumijevanju zajedništva svetih u svjetlu pentekostalno-rimokatoličkog dijaloga, svakako treba odgovoriti na dva pitanja: 1) Zašto je uveden ovaj kasniji dodatak Vjerovanju? 2) Zašto bi bilo korisno da se evanđeoski kršćani i pentekostalci više zadržavaju na njegovu razumijevanju?

Kako bi se odgovorilo na prvo pitanje, treba jasno reći da, pošto znanstvenici još nisu uspjeli odrediti točan uzrok „nadogradnje“ Vjerovanja, postoji opće slaganje da je cilj bio objaviti i obraniti istinu u odnosu na heretičko protivljenje, kao i artikulirati minimalne nepromjenjive dogmatske pretpostavke nakon što je Crkva o njima zauzela svoj konačan stav. Hans Küng $(1993,141)$ je, primjerice, vjerovao da je novi pojam uveden kako bi se ojačao communio fidelium, složena slika Crkve kao zajednice vjernika. Rana je Crkva načinom štovanja nastojala ne promicati individualističke ili izolacionističke oblike pobožnosti. Nasuprot tomu, kao što je tvrdio Tillard $(2001,33)$, prve su kršćanske zajednice pokazale stvarno, 
premda krhko zajedništvo u zajedničkoj vjeri ujedinjenosti u jedno tijelo i zajedničkoj posvećenosti Kristu po Duhu Svetom.

Drugi razlog za integriranje dodatnog dijela teksta Vjerovanja, o kojem također ovisi i odgovor na drugo pitanje, jest promjena paradigme u načinu na koji su kršćani razumijevali svoju duhovnost i svrhu koju donosi u njihov život. U skladu s učenjima Isusa, koji je pokrenuo novu teološku i društvenu paradigmu, udovoljavajući duhovnim i društvenim potrebama svojih sljedbenika (vidi Mt 4-5), IV. je stoljeće, nakon Nicejskog koncila, obilježila odlučujuća prekretnica u životu Crkve, koja je tada jasno prihvatila i uvidjela potrebu za aktivno uključivanje u život društva. Budući da nije bilo teško razumjeti da je car Konstantin pri okupljanju koncila bio motiviran svojim duboko ukorijenjenim uvjerenjem da religija ima društvenu funkciju, Crkva je u razdoblju od 380. do 450 . godine bila prisiljena duboko promišljati o svojoj ulozi u društvu. I kao što primjećuje Philip Rousseau (2002, 237), Crkva je do tada već dosegla potrebnu razinu teološke sofisticiranosti, pri čemu je bila sposobna na novi način raspravljati o odnosu između religije i javnoga društvenog života.

Ova posljednja ideja nam omogućuje da napravimo poveznicu s odgovorom na drugo prethodno spomenuto pitanje: zašto je korisno istraživati pentekostalno razumijevanje pojma communio sanctorum? Puno je mogućih „dobrobiti“, ali ovdje ću spomenuti samo tri, koje su po mom mišljenju najvažnije. Kao prvo, s obzirom na zadivljujuću globalnu raznolikost pentekostaliz(a)ma i općeniti manjak pentekostalnih eklezioloških promišljanja, za pentekostalce je ne samo korisno već i gotovo nužno raditi na izrazitije artikuliranoj ekleziologiji, sve sa svrhom boljeg definiranja vlastita ekleziološkog identiteta. Drugo, s obzirom na važno mjesto koje doktrina communio sanctorum zauzima u teologiji Katoličke Crkve (i drugih protestantskih crkava), kao i s obzirom na činjenicu da se taj pojam pokazao kao izvrsno zajedničko žarište za gradnju međusobnog razumijevanja, to će pomoći pentekostalcima da se bolje uključe u prijekopotreban širi ekumenski dijalog. Treće i najvažnije, budući da je to ranoj Crkvi izvorno omogućilo jasan teološki motiv za razmišljanje o njezinu odnosu prema javnom življenju, pentekostalci koji se sve više uključuju u društveni, politički i gospodarski život, mogli bi to iskoristiti kao plodnu teološku podlogu za oblikovanje svog javno-društvenog angažmana.

\section{Pregledni prikaz dokumenta Perspektive koinoniae}

Jedan od najvažnijih dokumenata o pentekostalnom načinu razumijevanja Crkve kao zajedništva svetih jest „Perspektive Koinoniae“ - izvješće Treće petogodišnjice dijaloga između Papinskog vijeća za promicanje jedinstva kršćana i odabranih klasičnih pentekostalnih crkava i njihovih lidera, 1985. - 1989. (Informativna 
služba 1990 / IV, 179-91). ${ }^{2}$ Ovaj međunarodni dijalog - vjerojatno najstariji i ekumenski najvažniji za pentekostalce, započeo je 1972. te traje sve do danas, a trenutno je u svojoj sedmoj fazi. ${ }^{3}$

Treća faza dijaloga, koja je od posebnog interesa za ovaj rad, bila je usredotočena na temu Crkve pod širim pojmom koinonia. ${ }^{4} \mathrm{U}$ okviru ove teme sudionici su raspravljali unutar sljedećih problemskih okvira: „Koinonia i Božja riječ“, „Duh Sveti i novozavjetna vizija koinoniae“, „Koinonia i krštenje“, „Koinonia u životu Crkve“ i „Koinonia i zajedništvo svetih“. U nastavku ćemo predstaviti neke od temeljnih ideja koje su sadržane u ovom dokumentu.

U uvodnom dijelu, urednici informiraju čitatelja da se tema „zajedništva svetih" pojavila tijekom druge faze dijaloga, kada su se rasprave usredotočile na Mariju, Majku Božju. Sudionici su smatrali da je tema „zajedništva“ izuzetno plodna prije svega u smislu otvaranja novih mogućnosti međusobnog približavanja te da ova tema može, štoviše, pobuditi rastući interes za svjetski ekumenski dijalog $(P C D 3,7)$.

Za pentekostalce, koinonia predstavlja važan aspekt crkvenog života, koji je povezan s radom Crkve u svijetu te s odnosima između kršćana. I rimokatolici i pentekostalci uviđaju važnost biblijske koinoniae, kako je prikazana u Djelima 2,42: „Bili su ustrajni u učenju apostolskog nauka, zajedničkom životu [koinonia], lomljenju kruha i molitvi“ $(P C D 3,10)$. Naravno, jedna od poteškoća svojstvenih ovakvom međuvjerskom dijalogu bila je izmiriti povijesnu razliku između visokorazvijene ekleziologije Katoličke Crkve i pentekostalne ekleziologije, koja je optimistično rečeno, bila tek $u$ procesu elaboriranja. Iako nemaju cjelovitu i zrelu crkvenost, pentekostalci ipak prihvaćaju širok spektar crkvenih politika i duboko im je stalo do određenih crkvenih uvjerenja, kao što je, primjerice, važnost lokalne skupštine $(P C D 3,11)$.

2 Izvješće su objavili Informativna služba (Information Service 1990 / IV, 179-91) i PNEUMA: Časopis Društva za pentekostalne studije (Završno izvješće, u Pneuma, vol. 12 (1), 1990, 85-95). Nadalje će se kratica PCD3 koristiti za to izvješće. Također, da bi čitatelju bilo lakše slijediti reference, neovisno o izdanju, referiranje na citate iz teksta $P C D 3$ odnosi se na broj članka (npr. „3“ znači članak 3), a ne na broj stranice.

3 Više o sedam faza dijaloga, primjerice raspored, teme, sudionici i mjesta događanja dostupno je na: https://www.prounione.it/dia/pe-rc/Dia-Pe-RC-Table-of-Contents-web.pdf (pristupljeno 25. veljače 2021.)

4 Važno je spomenuti da se o temi koinoniae razgovaralo kasnije u četvrtoj fazi dijaloga (1990.1997.), u kontekstu evangelizacije i društvene pravde. Završni dokument, koji je naslovljen „Evangelizacija, prozelitizam i zajedničko svjedočenje: Izvješće iz četvrte faze međunarodnog dijaloga između Katoličke Crkve i nekih klasičnih pentekostalnih crkava i njihovih lidera (1990.-1997.)“ može se preuzeti na poveznici https://www. prounione.it/dia/pe-rc/Dia-PeRC-04_1997.pdf. Da bi čitatelju bilo lakše slijediti referiranje na dijelove teksta PCD4, umjesto brojeva stranica, naznačuju se brojevi članaka (npr. „5“ znači članak 5). 
Također, treba imati na umu da u Odjeljku IV / B, pod naslovom „Crkva kao koinonia“, članak 73. kaže da „važnost aktivnog odgovora na Božje darove u službi koinoniae zahtijeva uzajamnost u mnogim njezinim dimenzijama“ $(P C D 3,73)$. Kako za katolike, tako i za pentekostalce, koinonia u Crkvi jest biblijski, dinamičan koncept koji „podrazumijeva strukturu dijaloga, kako u odnosu na ono što je bogomdano, tako i u odnosu na ljudski odgovor" $(P C D 3,73)$. Ovaj koncept traži uzajamnost na svim razinama Crkve, a izvor mu je trajna prisutnost Duha Svetoga $(P C D 3,73)$.

Izvještaj „Perspektive koinonia““ također spominje poteškoće s kojima se suočavaju pojedini pentekostalci u odnosu na crkvene institucije, što nastaje zbog izrazitog naglašavanja izravnog odnosa s Duhom. Čini se da su pentekostalni kršćani skloni zaboraviti da se Duh ne daje samo pojedincima već cijeloj zajednici. Katolici su pozivali pentekostalce da cijelu zajednicu vide kao „hram Božji“ u kojem prebiva Duh Sveti (PCD3, 76).

Posebna će se pažnja sada posvetiti odjeljku V. Izvještaja, koji je naslovljen „Koinonia i zajedništvo svetih“. Ovaj odjeljak obuhvaća članke 95. do 198. te ima dva dijela: A) Crkva kao communio sanctorum i B) Svetost, pokajanje i služba kroz povijest. U pokušaju da ocrtaju što svaka od strana razumije kada definira Crkvu kao communio sanctorum, sudionici smatraju da nas Bog poziva na zajedništvo sa samim sobom (communio sa Svetim), s tijelom i krvlju Kristovom (communio in sanctis), kao i s drugim kršćanima (zajedništvo svetih: communio sanctorum).

Pod izrazom communio in sanctis, katolici smatraju da je „sudjelovanje u krštenju, krizmi i euharistiji sastavni dio Crkve" $(P C D 3,96)$, dok je za pentekostalce „središnji element štovanja propovijedanje Riječi“ $(P C D 3,96)$. „Dok osobe odgovaraju na objavljivanje Riječi, Duh im daje novo rođenje, koje predstavlja predsakramentalno iskustvo, čineći ih kršćanima te u tom smislu stvarajući Crkvu“ (PCD3, 96).

Što se tiče pojma communio sanctorum, katolici smatraju da ta sintagma u Nicejskom vjerovanju ima eshatološko značenje, pozivajući se na činjenicu da sveti na zemlji i na nebu, zapečaćeni istim Duhom, čine jedno Tijelo $(P C D 3,95)$. Stoga, u skladu s katoličkim poimanjem, pojam communio sanctorum znači odnos sa svim Božjim svetima, kako na zemlji tako i na nebu. Članovi Crkve uživaju koinoniau sa samom Božjom svetošću. Kao rezultat, oni predstavljaju „velik oblak svjedoka“ (Heb 12,1) i čine, kako kaže Otkrivenje 7,9 „veliko mnoštvo koje nitko nije mogao izbrojiti... iz svakoga naroda, plemena, rase i jezika" $(P C D 3,99)$.

Poznata je činjenica da za katolike prakticiranje vjere uključuje razliku između latria ili štovanje Boga i dulia ili štovanja svetaca, koji su završili svoju trku i primili krunu života $(P C D 3,100)$. Pozivajući se na isti biblijski tekst (Heb $12,1)$, pentekostalci su se složili da se njihovu štovanju svetih na zemlji pridružuje štovanje svetih na nebu, čime nastaje jedna sveta, katolička i apostolska Crkva 
$(P C D 3,101)$. Drugim riječima, pentekostalci ne upućuju ni jednu vrstu štovanja (latria ili dulia) svetima, već zajedno sa svetima, štuju isključivo Boga.

Doduše, pojam communio sanctorum objedinjuje dvije vrlo važne teme za kršćansku vjeru općenito, a posebno za pentekostalizam: zajedništvo i svetost. $S$ crkvenog stajališta, nije moguće govoriti o zajednici svetih, a da se pritom ne govori o zajedništvu, ali također i o posvećenju. Tako su se, promišljajući o svetosti Crkve, kao i o potrebi pokajanja Crkve, svi sudionici složili oko barem tri pitanja: 1) svi krštenici su pozvani biti „sveti“ i stoga, prema Svetom pismu, sami sebe tako nazivaju u ranoj Crkvi $(P C D 3,102) ; 2)$ zbog grijeha, Crkva uvijek treba pokajanje, s tim da je istodobno sveta, ali joj je istovremeno potrebno pročišćenje ili obnova, kako na razini pojedinaca, tako i u svim njezinim strukturama $(P C D 3$, 103); 3) iako uvjet da svećenik/pastor treba živjeti u svetosti predstavlja temeljno crkveno načelo, njegova nedostojnost ipak nije u stanju onemogućiti djelovanje Duha Svetoga $(P C D 3,104)$.

Kao što navodi Veli-Matti Kärkkäinen, pentekostalna ekleziologija, koja je sve donedavno bila ograničena na karizmatsko iskustvo i imala sklonost karizmatskoj strukturi Crkve, koja je otvorena za protok Duha, bila je sada prisiljena, licem u lice s Katoličkom Crkvom, dublje promišljati o odnosu Duha Svetoga, institucije i koinoniae: „Kao karizmatsko zajedništvo, Crkva je zajednica aktivno sudjelujućih, Duhom osnaženih vjernika“ (Kärkkäinen 2001, 100). To nas dovodi do trećeg i završnog dijela ovoga članka.

\section{Pentekostalni način razumijevanja pojma communio sanctorum: „Prema teologiji Crkve kao zajedništva osoba“}

Pentekostalno-rimokatolički dijalog održao se 21. - 26. svibnja 1985. u Rianu u Italiji. Bio je pod jakim utjecajem dokumenta, koji su predstavila dva pentekostalna teologa iz bivše Jugoslavije: Peter Kuzmič i Miroslav Volf. Članak „Communio Sanctorum: Prema teologiji Crkve kao zajedništva osoba" nije pretjerano vidjeti kao prvi pokušaj pentekostalaca da artikuliraju svoje ekleziološke vizije utemeljene na ideji communio sanctorum. U posljednjem ćemo se dijelu ovoga članka kritički osvrnuti na ekleziološki stav Kuzmiča i Volfa, a zatim pokazati od kakve je koristi u razvoju pentekostalne teologije javnoga društvenog života.

Kuzmič i Volf su u svom radu razvili ideju strukture karizmatske Crkve koja se temelji na konceptu koinoniae, tvrdeći da je zajedništvo ključ ispravnog strukturiranja Crkve: „Pentekostalna soteriologija i pneumatologija pokazuju... nepogrešivo u smjeru ekleziologije zajedništva osoba" (Kuzmič i Volf 1985, 2). Autori tvrde da novozavjetni tekstovi poput, primjerice, onog u 1. Korinćanima 12,13 pokazuju da je „zajedništvo bilo uobičajeno iskustvo krštenja u tijelo Kristovo po Duhu“ (Kuzmič i Volf 1985, 14). 
U članku u kojem predstavlja odabrane ekleziološke refleksije iz pentekostalno-rimokatoličkog dijaloga, Kärkkäinen analizira stav Kuzmiča i Volfa koji je iznesen u njihovu radu te zaključuje da su „nastojali razviti pentekostalno viđenje Crkve kao karizmatskog zajedništva u pneumatološki konstruiranoj stvarnosti“ (Kärkkäinen 2001, 114). Drugim riječima, zajedništvo je nešto što se živi, doživljaj življenja koji dijelimo s drugima u svakodnevnom životu zajednice. Kärkkäinen ističe kako se „na pitanje 'Gdje je crkva?' ne može odgovoriti bez pozivanja na živu prisutnost Duha Svetoga" (Kärkkäinen 2001, 114) te u jednoj od svojih bilješki primjećuje kako Kuzmič i Volf citiraju iz djela Lesslie Newbigina The Household of God (Božje kućanstvo), gdje se uspoređuju protestantska, rimokatolička i pentekostalna viđenja Crkve (Kärkkäinen 2001, 114).

U skladu s onim što se iznosi u radu Kuzmiča i Volfa, postoje tri osnovna modela strukturiranja Crkve. Prvi, specifičan za klasični protestantizam, jest model „predavaonice“, gdje je naglasak na propovijedanju iz Biblije. Drugi, koji karakterizira poimanje Katoličke Crkve, jest model „predstave“, gdje je naglasak na dramatskim elementima štovanja. Treći je model „pentekostalnog zajedništva“, gdje je naglasak na vidljivom okupljanju zajednice sa svrhom međusobnog izgrađivanja u vjeri (Kuzmič i Volf 1985, 14-6). Bez namjere isključivanja elemenata, koji su povezani s propovijedanjem Riječi ili javnim izvođenjem akta štovanja, Kuzmič i Volf sugeriraju da temeljnu odrednicu novozavjetnog štovanja predstavlja zajedništvo vjernika (Kuzmič i Volf 1985, 15). ${ }^{5}$

Citirajući Newbigina, Kuzmič i Volf navode kako je „stvarni život vjerske zajednice, u kojoj svaki član ima prilike pridonijeti životu cijeloga tijela korištenjem darova kojima ga obdaruje Duh Sveti, uvelike sastavni dio života Crkve, jednako kao što su to služba i sakramenti“ (Kuzmič i Volf 1985, 16). Drugim riječima, dinamika zajedništva može se konkretno vidjeti u korištenju darova Duha od strane svakog vjernika, u korist ili za izgradnju zajednice. Zaključak rada, koji su Kuzmič i Volf predstavili na ekumenskim razgovorima u Rianu, vrijedi citirati u cijelosti:

Jasno je: nema društvenog tijela koje može trajno postojati bez struktura. Crkva pritom nije iznimka. U slučaju Crkve je, međutim, od temeljne važnosti da strukture koje ona razvija budu kompatibilne sa slobodom i suverenošću Duha u njezinim vlastitim redovima. Novozavjetna ekleziologija sugerira

5 Miroslav Volf je u vrlo cijenjenoj knjizi kasnije razvio svoje ideje, postavljajući temelje „participativne ekleziologije“. Vidi Miroslav Volf. 1998. After Our Likeness: The Church as the Image of the Trinity. Grand Rapids: Eerdmans. Tu Volf skicira neke od osnovnih značajki participativne ekleziologije, crpeći nadahnuće od Johna Smytha, prvog baptističkog teologa, i upuštajući se u kritički dijalog s rimokatoličkom ekleziologijom, zastupanom po kardinalu Josephu Ratzinge$\mathrm{ru}$, te s pravoslavnom ekleziologijom koju je predstavljao metropolit Ioannis Zizioulas. 
da se pneumatokracija ne može postići pravno strukturiranom hijerarhijom. Iako se može činiti paradoksalnim, ako Crkvom doista treba vladati odozgo, njezine strukture moraju izrastati odozdo. Razlog je jednostavan: budući da svi članovi imaju Duha, nitko od njih ne može monopolizirati Njegovo vođenje. Budući da je vodstvo Duha privilegija svih članova Crkve, strukture karizmatičnog zajedništva moraju nastati interakcijom svih njegovih članova. Sociološki gledano, one se trebaju oblikovati prema zakonitostima dinamike oblikovanja odabrane zajednice. To znači da se posebna pažnja treba posvetiti tome da strukture koje nastaju odozdo ostaju stalno povezane sa svakodnevnim životom zajednice. Inače razvijaju tendenciju da se osamostale i ometaju život, umjesto da ga podržavaju (Kuzmič i Volf 1985, 23). ${ }^{6}$

Tri se stvari mogu izdvojiti u vezi ekleziološke vizije koju predlažu Kuzmič i Volf, vizije koja je u skladu s pentekostalnom perspektivom koinoniae, kako je prikazana u Završnom izvješću pentekostalno-katoličkog dijaloga. Kao prvo, stalno se ističu tri značajke koje, prema mišljenju autora, određuju pentekostalno razumijevanje Crkve: zajedništvo, karizmatsko zajedništvo i karizmatski strukturirano zajedništvo (Kuzmič i Volf 1985, 23). Ova trijada naglašava da pentekostalci poimaju zajedništvo svetih iz perspektive koja nije eklezijalna (suština zajedništva nije u postojanju hijerarhijskih crkvenih struktura) ili sakramentalna (suština zajedništva nije u imanju i prakticiranju sakramenata), već je pneumatološka: prisutnost Duha Svetog, kroz Njegove darove koji se očituju u svim vjernicima, sa svrhom međusobnog izgrađivanja svetih.

Kao drugo, Kuzmič i Volf ne zaboravljaju naglasiti eshatološku narav Crkve: „Kao karizmatski strukturirano zajedništvo, Crkva je svjetionik nade usred starog, slomljenog i podijeljenog svijeta“ (Kuzmič i Volf 1985, 23-4). Iako prethodno spomenuta trijada ima svrhu definiranja zajedništva svetih, ovaj eshatološki naglasak, prema našem mišljenju, želi ukazati na pentekostalno poimanje svetosti zajedništva; drugim riječima, odrediti svrhu Crkve u svijetu kao zajednice svetosti. To sugerira da pripadnici karizmatskog zajedništva svojim svetim bivanjem - odvojeni od svijeta, ne samo da teže dobrobiti svoje zajednice, koristeći se svojim duhovnim darovima za međusobno izgrađivanje, već također svojom

6 "It is clear: no social body can permanently exist without structures. The church is no exception. In the case of the Church, however, it is of fundamental importance that the structures it develops be compatible with the freedom and sovereignty of the Spirit in its own ranks. The New Testament ecclesiology suggests that pneumatocracy cannot be accomplished through the juridically structured hierarchy. Though it may seem paradoxical, if the Church is truly to be ruled from above, its structures must arise from below. The reason is simple: since all members have the Spirit, no one of them can monopolize his leading. Since the Spirit's leading is a privilege of all members, the structures of a charismatic fellowship have to arise through the interaction of all its members. Sociologically speaking, they have to be formed according to the laws of group formation. This means that special care has to be given to see that the structures born from below continually remain an outgrowth of the concrete life of the community. Otherwise they develop a tendency to become independent and hinder life instead of helping it." 
prisutnošću i posvećenim životom usred svijeta doprinose općem dobru i održavaju živu nadu posvećenja svega stvorenog. Niti sljedeći se aspekt ne smije zanemariti: ideja zajednice/zajedništva je od samog početka imala veliku važnost za pentekostalni pokret jer pristašama pruža sigurno utočište od vjerskih, kulturnih i političkih anomalija i zloporaba.

Kao treće, Kuzmič i Volf uspostavljaju vezu između očitovanja darova Duha Svetog u zajedništvu i javnog djelovanja Crkve u svijetu: „Na isti način kao što bi zajedništvo trebalo biti nedvojbeno obilježje Crkve, tako bi i duhovni darovi vjernika trebali biti trajno obilježje njezina življenja" (Kuzmič i Volf 1985, 16). Stoga, postoji neposredna povezanost između karizmatske, posvećujuće i na zajedništvo potičuće prisutnosti Duha Svetoga te načina na koji karizmatsko zajedništvo svetih opstoji u svijetu. Jasno je da su ove značajke, zajedno s idejom karizmatskog zajedništva svih ljudi, od posebnog značaja za opstojanje Pentekostalne Crkve u svijetu te impliciraju njezin odnos prema javnom društvenom životu.

Sada je važno da kritički procijenimo pentekostalnu perspektivu koja proizlazi iz izvješća „Perspektive koinonae“, imajući na umu postavke koje u svom radu iznose Peter Kuzmič i Miroslav Volf. Evo tri pitanja koja su od posebnog značaja za naš članak: 1) Koji su razlozi za to da su pentekostalci tako spremno prihvatili donekle ekumenski pojam koinoniae kao način gledanja na Crkvu? 2) Koje su razlike između pentekostalnog i rimokatoličkog razumijevanja zajedništva svetih? te 3) Kakav utjecaj ima takvo viđenje communio sanctorum na oblikovanje pentekostalne teologije javnoga društvenog života?

Odgovor na prvo pitanje je vjerojatno trostruk. Dakle, prvi razlog zašto je tema koinoniae tako privlačna pentekostalnim teolozima jest njezina biblijska dosljednost, odnosno snažna utemeljenost u tekstu Svetog pisma (Tillard 1992, 2-20). Iako njegov sažetak ima slabiji sakramentalni odjek za pentekostalce, Kilian McDonnell, tadašnji supredsjedatelj Dijaloga, dobro sažima biblijsku perspektivu Djela apostolskih, omiljene knjige pentekostalaca: „Dakle, ako je netko istinski vjeran dinamici Djela, odmah bi nakon predaje Duha dodao koinoniau/ zajedništvo, tj. oblikovanje zajednice zajedno s njezinim euharistijskim izražajem. Lukin jezik jest jezik zajednice" (McDonnell 1988, 674, kurziv dodan). Stoga, može se reći da u najelementarnijem smislu koinonia označava zajedništvo, zajednicu, sudjelovanje, ali također i zajedništvo na duhovnoj, socijalnoj i materijalnoj razini. Iz biblijske perspektive, koinonia također obuhvaća trinitarnu i pneumatološku dimenziju, kao što je to vidljivo u , apostolskom blagoslovu“ (2 Kor 13,13).

Drugi razlog zašto su pentekostalci tako spremno prihvatili viziju koinoniae je možda zato što je snažno usklađena s načinom na koji pentekostalni pokret vrednuje „zajedništvo“ u odnosu na ,instituciju“ ili „hijerarhiju“ Crkve. U pentekostalnom učenju, koinonia se poima kao ključan aspekt života Crkve, koji je blisko povezan s njezinom službom u svijetu te s odnosima između kršćana“" $(P C D 3$, 
10). Pentekostalni teolog Howard M. Ervin u tom smislu piše da „Pentekostalno naglašavanje novog rođenja i krštenja Duhom poima osobnu koinoniau Sina i Duha Svetoga veoma ozbiljno“ (Ervin 1987, 8-9).

Treći razlog spremnog prihvaćanja ekleziologije, koja se temelji na koinoniai jest način na koji kršćani pentekostalci razumiju povezanost između bogoslužja i crkvenog života. Za pentekostalce se dinamika zajedništva izražava kroz očitovanje darova Duha Svetoga. U tom je smislu Daniel Albrecht $(1999,22)$ u pravu kada tvrdi da je „Pentekostalno bogoslužje u samoj srži pentekostalne/karizmatske duhovnosti te sudjelovanje u obredima i drugim praksama čini središnji i najvažniji obred pentekostalizma“. Slijedom toga, liturgijsko iskustvo (bogoslužje) obilježeno žarkom željom za „susretom s Gospodinom“ predstavlja samu srž pentekostalnog života Crkve. Čak i onda kada duhovne manifestacije govorenja u jezicima, prorokovanja ili iscjeljivanja povremeno izostaju, trajno postoji stvarna otvorenost i spremno iščekivanje opipljivih znakova Božje prisutnosti u zajedništvu svetih.

$\mathrm{Na}$ drugo prethodno postavljeno pitanje, koje je u vezi s konfesionalnim razlikama u razumijevanju pojma koinonia, kompetentno odgovara Veli-Matti Kärkkäinen u svojoj knjizi Spiritus uni vult spirat. Iako je ulomak prilično dugačak, vrijedi ga navesti u cijelosti. Dakle, glavne razlike:

...imaju veze s četiri osnovna pitanja, od kojih je prvo najznačajnije: sakramenti, odnos između lokalne i univerzalne Crkve (podrazumijevajući također i odnose između lokalnih crkava), karizmatske ili hijerarhijske strukture Crkve te jedinstvo Crkve. Osnovna razlika u poimanju sakramenata vezana je uz katoličku postavku da su sakramenti (krštenje, euharistija) sastavni dio Crkve. Pentekostalna strana usprotivila se toj tvrdnji. Za pentekostalce su propovijedanje Božje riječi i svjesni odgovor pojedinaca vjerom sastavni dio Crkve. Druga se razlika odnosi na pitanje prioriteta i odnosa između lokalne Crkve i univerzalne Crkve. Sasvim prirodno, katolici stavljaju izrazitiji naglasak na univerzalnu Crkvu, dok je za pentekostalce najvažnija lokalna Crkva, gotovo do razine isključivanja univerzalne. Međutim, katolička teologija nakon II. Vatikanskog koncila sve više vrednuje ulogu lokalne Crkve iako još uvijek nedostaje definitivno stajalište o točnom odnosu između lokalne i univerzalne Crkve. S obzirom na poimanje karizmatske nasuprot hijerarhijskoj strukturi Crkve, katolici naglašavaju važnost uloge hijerarhije, crkvenog autoriteta i struktura te ih vide kao 'bogomdane' i one koje same po sebi izražavaju koinoniau. Pentekostalci biraju veću 'slobodu' Duha te u tom kontekstu poimaju crkvene strukture kao manje važne, iako važne u ostvarivanju reda. O teškom pitanju jedinstva kršćana također se raspravljalo tijekom okupljanja povodom treće petogodišnjice Dijaloga, posebice u kontekstu koinoniae. Pitanje jedinstva Crkve i dalje ostaje važno za raspravu. Za katolike postoji samo jedna vidljiva Kristova Crkva. Sve podjele u Crkvi se smatraju odstupanjem od toga temeljnog jedinstva. Za pentekostalce je postojanje denominacija uglavnom legitiman razvoj događaja. Pentekostalci misle prvenstveno u smislu duhovnog, tj. nevidljivog jedinstva (isključivo). Izražavaju nekoliko sumnji s obzi- 
rom na strukturalno/vidljivo jedinstvo, primjerice kompromitiranje doktrine, propast evangelizacije itd. (Kärkkäinen 1998, 109-10).?

I tako sada dolazimo do trećeg pitanja, koje je možda najvažnije: Koji je doprinos ove crkvene vizije u oblikovanju pentekostalne teologije javnoga društvenog života? Nadamo se da je iz dosad iznesenog potpuno jasno kako razvoj ekleziologije, utemeljen na pojmu koinonia, sadržava ogroman potencijal za daljnji razvoj pentekostalnog pokreta.

U prvobitnom članku, objavljenom u PentecoStudies, Kärkkäinen ukazuje na pet „zanemarenih ili nedovoljno razvijenih obilježja“ ekleziologije drugih crkava, kojima pentekostalna ekleziologija može biti od pomoći: „dinamična narav koinoniae“, „koinonia kao poziv na svetost“, „misijsko djelovanje i društvena pravda u kontekstu koinonia-ekleziologije“, „darovi Duha i koinonia“ te „koinonia kao eshatološka stvarnost“ (Kärkkäinen 2007, 8). Iako su sve ove značajke važne, usredotočit ćemo se na samo dvije od njih, koje imaju posebno veliku važnost za razvoj naše argumentacije: koinonia kao poziv na svetost te koinonia kao društvena pravda.

U skladu s dinamičnom naravi samog koncepta, pentekostalno poimanje Crkve kao karizmatskog zajedništva pojedinaca je također svojevrsni poziv na svetost (Kärkkäinen 2007, 8). Poznati pentekostalni teolog Amos Yong u tom smislu postavlja retoričko pitanje: „Čime bi, dakle, pentekostalci mogli doprinijeti širem eklezijalnom shvaćanju svete Crkve?“, a potom nudi odgovor: „Možda je specifičan pentekostalni doprinos crkvenom ekumenizmu upravo to pneumatološki

7 "...had to do with four basic issues, the first being the most substantial: sacraments, local vs. universal church relationship (including relationship between local churches), charismatic vs. hierarchical structure of the church, and oneness of the church. The basic difference in the view of sacraments had to do with the Catholic claim that sacraments (baptism, Eucharist) are constitutive of the church. The Pentecostal side opposed this claim. For Pentecostals, preaching of the word and conscious faith response of the individuals are constitutive of the church. The other divergence related to the question of the priority of and relationship between the local church and universal church. Quite naturally, Catholics place more emphasis on the universal, while for Pentecostals the local church is the most important, almost to the exclusion of the other. However, Catholic theology, after Vatican II has come to appreciate more and more the role of the local church, although a definitive standpoint is still lacking as to their precise relationship. When it comes to charismatic vs. hierarchical structure of the church, Catholics emphasize the role of hierarchy, church authority, and structures, and see them as 'God given' which in themselves express koinonia. Pentecostals opt for greater 'freedom' of the Spirit and see structures as subordinate to, although important in guaranteeing order. The difficult question of Christian unity was also discussed during the third quinquennium in relation to koinonia. The question of the oneness of the church still remains a substantial point of contention. For Catholics, there is only one visible church of Christ. All divisions in the church are regarded as deviation from this basic unity. For Pentecostals, the existence of denominations is for the most part a legitimate development. Pentecostals think primarily in terms of spiritual, i.e., invisible unity (only). They have several misgivings about the structural/visible unity, e.g., the compromise of doctrine, the demise of evangelism, etc." 
robusno poimanje posvećujuće preobrazbe“ (Yong 2005, 140). Ova je postavka iznimno važna pošto naglašava važnost društvene dimenzije svetosti, odnosno odnose unutar Crkve kao communio sanctorum, ali također i odnos između Crkve i svijeta - dimenzija koja je od samog početka Pokreta uvijek bila istaknuto obilježje pentekostalne duhovnosti.

Kärkkäinen također ističe da su pentekostalci često veoma kritični prema onome što doživljavaju kao „samozadovoljstvo“ starijih crkava u odnosu na članove za koje se čini da žive u grijehu, a ipak su prihvaćeni kao članovi Crkve (Kärkkäinen 2007, 8). Za pentekostalce to nije prihvatljivo jer izgleda kao da takva situacija zanemaruje novozavjetno poimanje koinoniae. Kao što primjećuje Yong, pentekostalno poimanje je u skladu s izjavom Thomasa Odena, prema kojoj je „presudan dokaz svetosti Crkve, ironično, sama činjenica da ona djeluje među grešnicima otkupljujući ih, tražeći ih, iscjeljujući ih i posvećujući“ (Oden 1992, 319, citirano u Yong 2005, 139).

I, na kraju, ali ne najmanje važno, pentekostalna ekleziološka vizija karizmatskog zajedništva među osobama povezuje pojam koinonia s konceptom društvene pravde, čime značajno doprinosi općem dobru. Crkva, kao zajedništvo osoba osnaženih karizmatičnom prisutnošću Duha Svetoga, nije zajednica koja živi samo za sebe. Prema Moltmannovim riječima, ona je "otvorena svijetu“ (Moltmann 1981, 89). Činjenica življenja u koinoniai, Crkvi omogućava da postane „dar svijetu i znak služenja svijetu“ $(P C D 4,26)$, „proročki znak za cijelo čovječanstvo (usporedi Iv 17,21)“ (PCD4, 14). Ili, kao što se navodi u članku 94. PCD3, „Kao novi Božji narod, Crkva je pozvana odražavati stvarnost Božjega eshatološkog kraljevstva u povijesti te objavljivati njegov dolazak u svijet, sve dok ljudi ne otvore svoje živote za prodor Duha Svetog“ (PCD3, 94). Stoga, budući da je Crkva zajednica s poslanjem, za nju je svojstveno da sudjeluje u patnjama svijeta i da ublažava siromaštvo, nepravdu i druga društvena zla. Možda jedan od najprikladnijih prikaza kako pentekostalci primjenjuju svoje razumijevanje communio sanctorum na život zajednice nalazimo u Završnom izvješću PCD4. Zaključujemo završni dio članka ovim važnim citatom:

Pentekostalci su u životu zajednice pronašli novi osjećaj dostojanstva i svrhu ljudskog življenja. Njihova solidarnost stvara afektivne veze, dajući im osjećaj jednakosti. Takve su zajednice funkcionirale kao društvena alternativa, protestirajući protiv ugnjetavačkih struktura društva u cjelini. Zajedno s nekim drugim društvenim kritičarima, pentekostalci su otkrili da se učinkovite društvene promjene često odvijaju na komunalnoj i mikrostrukturalnoj, a ne prvenstveno na makrostrukturalnoj razini $(P C D 4,43){ }^{8}$

8 "In the life of the community, Pentecostals have found a new sense of dignity and purpose in life. Their solidarity creates affective ties, giving them a sense of equality. These communities have functioned as social alternatives that protest against the oppressive structures of the society at large. Along with some social critics, Pentecostals have discovered that effective 


\section{Zaključak}

U prvom je dijelu članka predstavljen kratak povijesni i teološki pregled pojma communio sanctorum, koji ukazuje na činjenicu da su znanstvena mišljenja podijeljena oko značenja tog izraza, što ga čini veoma diskutabilnim, ali svakako ne u smislu njegove važnosti kao iskaza vjere. Naravno, razlike u dogmatskim tumačenjima nastaju zbog načina na koje različite kršćanske tradicije tumače svaki od pojmova (zajednica/zajedništvo, svetost) unutar samog izraza, pri čemu su katolički teolozi skloniji izrazitije mističnom razumijevanju, dok evanđeoski/pentekostalni teolozi daju prednost izrazitije društveno orijentiranom tumačenju. Međutim, jedan od razloga zašto je communio sanctorum integriran u Apostolsko vjerovanje je taj što odražava sporazumnu promjenu paradigme u načinu na koji su kršćani razumjeli svoju duhovnost i značenje koje donosi u njihov (javni) život. Ustvrdili smo da postoji potreba za kontinuiranim i ozbiljnim teološkim promišljanjem suvremenog značenja pojma i implikacija zajedništva svetih pošto će to omogućiti ne samo jasnije samorazumijevanje ekleziološkog identiteta već i oblikovanje ekleziološki prilagođene teologije sudjelovanja u javnom životu društva.

U drugom se dijelu članka iznose najvažnije rimokatoličke i pentekostalne perspektive poimanja pojma koinonia, kao što su predstavljene u završnom Izvješću treće petogodišnjice dijaloga 1985. - 1989. To je, nadamo se, pomoglo identificirati osnovne konvergentne i divergentne ideje koje su dolazile s obje strane uključene u dijalog, ukazujući na potrebu za snažnijim pentekostalnim promišljanjem odnosa između Duha Svetoga, institucije Crkve i pojma koinonia, čime se oblikuje osnova za bolje razumijevanje pentekostalnog stava. Treći i posljednji dio članka predstavio je i kritički analizirao dokument Kuzmiča i Volfa, koji je bio predstavljen na Dijalogu u Rianu, i smatra se prvim akademskim pokušajem skiciranja pentekostalnog razumijevanja pojma communio sanctorum. Suprotstavljajući pentekostalni model crkvene strukture „zajedništva“ s rimokatoličkim modelom „predstave“ te protestantskim modelom „predavaonice“, Kuzmič i Volf tvrde da pentekostalna soteriologija i pneumatologija jasno upućuju na ekleziologiju zajedništva vjernika. Ovdje se, svakako, radi o karizmatskom zajedništvu posvećenih i Duhom osnaženih osoba, pri čemu se izraz „karizmatski“ odnosi na dinamičnu i konkretnu uporabu charismata, i to od strane svakog vjernika sa svrhom izgradnje cijele zajednice. Osim ovoga važnog zaključka, također smo utvrdili da Kuzmič i Volf ističu eshatološku dimenziju opstojanja Crkve u svijetu, koja podrazumijeva praktične, svakodnevne, društveno preobražavajuće implikacije.

social change often takes place at the communal and micro-structural level, not at the macrostructural level." 
Da zaključimo, očito je pentekostalna ekleziološka vizija, koja communio sanctorum razumije kao karizmatsko zajedništvo vjernika, bremenita potencijalom stvaranja robusnog društveno-praktičnoga teološkog obrasca pentekostalne teologije javnoga društvenog života. Možemo se samo složiti s prethodno spomenutom smjelom izjavom Amosa Yonga, da je „pentekostalni dar ekumenskoj Crkvi pneumatološki robustan pojam posvećujuće preobrazbe“"(Yong 2005, 140).

\section{Literatura}

${ }^{* * *}$ Evangelisation, Proselytism and Common Witness: The Report from the Fourth Phase of the International Dialogue between the Roman Catholic Church and Some Classical Pentecostal Churches and Leaders (19901997). https://www.prounione.it/dia/pe-rc/Dia-Pe-RC-04_1997.pdf (pristupljeno 26. veljače 2021.).

*** Perspectives on Koinonia. Report from the Third Quinquennium of the Dialogue between the Pontifical Council for Promoting Christian Unity and Some Classical Pentecostal Churches and Leaders, 1985-1989. Information Service 75 (1990/IV), 179-191. http://www.prounione.urbe.it/ dia-int/pe-rc/doc/e_pe-rc_pent03f.html (pristupljeno 14. veljače 2021.).

Albrecht, E. Daniel. 1999. Rites in the Spirit: A Ritual Approach to Pentecostal/ Charismatic Spirituality. Sheffield: Sheffield Academic.

Ayo, Nicholas. 1990. The Creed as Symbol. Notre Dame: University of Notre Dame Press.

Barclay, William. 1967. The Plain Man Looks at the Apostles' Creed. Glasgow: Fontana Books.

Badcock, F. J. 1938. The History of the Creeds. New York: MacMillan.

Brown, Peter. 1981. The Cult of the Saints: Its Rise and Function in Latin Christianity. Chicago: University Press.

Benko, Stephen. 1964. The Meaning of Sanctorum Communio. London: SCM Press.

Burn, A. E. 1964. Niceta of Remesiana, His Life and Works. Cambridge: Cambridge University Press.

Carson, Thomas i Cerrito, Joann (ur.). 2003. New Catholic Encyclopaedia, vol. 4, 2nd edition. USA: Gale.

DeLorenzo, Leonard J. 2017. Work of Love: A Theological Reconstruction of the Communion of Saints. Notre Dame: University of Notre Dame Press. 
Ervin, Howard. 1987. Koinonia, Church and Sacraments: A Pentecostal Response, unpublished paper, presented at the International Pentecostal-Catholic Dialogue in Venice, 1-8 August 1987. https://digitalshowcase.oru.edu/cgi/ viewcontent.cgi?referer=https://www.google.com/\&httpsredir=1\&article=1 005\&context=ervin_bio (pristupljeno 24. studenoga 2020.).

Heurtley, Charles A. 1858. Harmonia Symbolica: A Collection of Creeds Belonging to the Ancient Western Church. Oxford: Oxford University Press.

Kuzmič, Peter i Volf, Miroslav. 1985. "Communio Sanctorum: Toward a Theology of the Church as a Fellowship of Persons". Unpublished Pentecostal position paper presented at the International PentecostalRoman Catholic Dialogue, Riano, Italy, May 21-26, 1985.

Imbelli, Robert P. 1998. "Friends of God and Prophets: A Feminist Theological Reading of the Communion of Saints". Commonwealth, 125 (18): 24-26.

Johnson, Elizabeth A. 1998. Friends of God and Prophets: A Feminist Theological Reading of the Communion of Saints. New York: Continuum.

Kärkkäinen, Veli-Matti. 1998. Spiritus ubi vult spirat: Pneumatology in Roman Catholic-Pentecostal Dialogue (1972-1989). Schriften dar Luther-AgricolăGesellschaft 42. Helsinki: Luther-Agricola Society.

Kärkkäinen, Veli-Matti. 2001. "Church as Charismatic Fellowship: Ecclesiological Reflections from the Pentecostal-Roman Catholic Dialogue". Journal of Pentecostal Theology 09: 100-121.

Kärkkäinen, Veli-Matti. 2007. "The Church as a Fellowship of Persons: An Emerging Pentecostal Ecclesiology of Koinonia”. PentecoStudies 6 (1): 1-15.

Kelly, J. N. D. 1972. Early Christian Creeds. Essex: Longman House.

Küng, Hans. 1993. Credo: The Apostles' Creed Explained for Today. London: SCM Press.

Marthaler, Berard. 2007. The Creed: The Apostolic Faith in Contemporary Theology, 3rd revised edition. New London, Connecticut: Twenty-Third Publications.

McDonnell, Kilian. 1998. "Communion Ecclesiology and Baptism in the Spirit: Tertullian and the Early Church". Theological Studies 49: 671-693.

Moltmann, Jürgen. 1981. The Trinity and the Kingdom: The Doctrine of God. Translated into English by M. Kohl. San Francisco: Harper \& Row.

Oden, Thomas. 1992. Systematic Theology, vol. 3, Life in the Spirit. San Francisco: HarperSanFrancisco.

Pelikan, Jaroslav. 2005. Credo: Historical and Theological Guide to Creeds and Confessions of Faith in the Christian Tradition. New Haven: Yale University Press. 
Rousseau, Philip. 2002. The Early Christian Centuries. London: Longman.

Tillard, Jean-Marie-Roger. 1992. Church of Churches: The Ecclesiology of Communion. Collegeville: Liturgical Press.

Tilllard, J. M. R. 2001. Flesh of the Church, Flesh of Christ, at the Source of the Ecclesiology of Communion. Collegeville: Liturgical Press.

Volf, Miroslav. 1998. After Our Likeness: The Church as the Image of the Trinity. Grand Rapids: Eerdmans.

Wood, Susan. 2004. "The Holy Catholic Church, the Communion of Saints". U: Roger Van Harn, ur. Exploring and Proclaiming the Apostles' Creed, str. 219-232. Grand Rapids: Wm. B. Eerdmans Publishing.

Yong, Amos. 2005. The Spirit Poured Out on All Flesh: Pentecostalism and the Possibility of Global Theology. Grand Rapids: Baker Academic.

Ciprian Gheorghe-Luca

\begin{abstract}
Toward a Pentecostal Understanding of Communio Sanctorum: Reflections on Peter Kuzmič \& Miroslav Volf's "Theology of the Church as a Fellowship of Persons" in the Context of the Pentecostal-Roman Catholic Dialogue
\end{abstract}

\begin{abstract}
The purpose of this paper is to reflect on the Pentecostal understanding of the communion of saints by critically engaging with the ecclesiological vision of two world-class Pentecostal theologians from post-communist countries: Peter Kuzmič and Miroslav Volf. The paper has three sections: in the first one, a brief historical and theological overview of the doctrine of communio sanctorum is presented, to both set the stage for the core of the paper, and to point out the usefulness of reflecting on this particular ecclesiological topic. The second section offers an outline of "Perspectives on Koinonia" (the final report from the Third Quinquennium of the Pentecostal-Roman Catholic Dialogue), focusing on the first round of talks (Riano, Italy, 1985), which were on the topic of communio sanctorum. In the third section, the author presents and engages with Kuzmic \& Volf's paper, "Theology of the Church as a Fellowship of Persons" which represents one of the earliest attempts to articulate a Pentecostal ecclesiology based on the notion of communio sanctorum. In the end, the author will attempt to show how this ecclesiological vision helps the shaping of a Pentecostal theology of public life.
\end{abstract}

